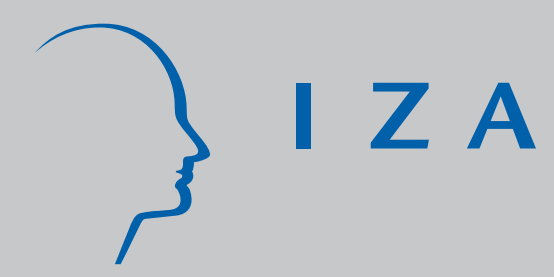

IZA DP No. 510

Wage Inequality in the United Kingdom, 1975-99

Eswar S. Prasad

J une 2002 


\title{
Wage Inequality in the United Kingdom, 1975-99
}

\author{
Eswar S. Prasad \\ International Monetary Fund and IZA Bonn
}

Discussion Paper No. 510
June 2002

IZA

P.O. Box 7240

D-53072 Bonn

Germany

Tel.: +49-228-3894-0

Fax: +49-228-3894-210

Email: iza@iza.org

This Discussion Paper is issued within the framework of IZA's research area Internationalization of Labor Markets. Any opinions expressed here are those of the author(s) and not those of the institute. Research disseminated by IZA may include views on policy, but the institute itself takes no institutional policy positions.

The Institute for the Study of Labor (IZA) in Bonn is a local and virtual international research center and a place of communication between science, politics and business. IZA is an independent, nonprofit limited liability company (Gesellschaft mit beschränkter Haftung) supported by the Deutsche Post AG. The center is associated with the University of Bonn and offers a stimulating research environment through its research networks, research support, and visitors and doctoral programs. IZA engages in (i) original and internationally competitive research in all fields of labor economics, (ii) development of policy concepts, and (iii) dissemination of research results and concepts to the interested public. The current research program deals with (1) mobility and flexibility of labor, (2) internationalization of labor markets, (3) the welfare state and labor markets, (4) labor markets in transition countries, (5) the future of labor, (6) evaluation of labor market policies and projects and (7) general labor economics.

IZA Discussion Papers often represent preliminary work and are circulated to encourage discussion. Citation of such a paper should account for its provisional character. A revised version may be available on the IZA website (www.iza.org) or directly from the author. 
IZA Discussion Paper No. 510

June 2002

\title{
ABSTRACT
}

\section{Wage Inequality in the United Kingdom, 1975-99*}

This paper uses micro data from the New Earnings Survey to document that cross-sectional wage inequality in the U.K., which rose sharply in the 1980 s and continued to rise moderately through the mid-1990s, has remained essentially unchanged in the latter half of the 1990s. As in the U.S., changes in within-group inequality are shown to account for a substantial fraction of the rise in wage dispersion that has occurred over the last 25 years. However, shifts in the structure of employment - including changes in the occupational and industrial composition of aggregate employment - are also shown to have had important effects on the evolution of wage inequality. In addition, there has been a significant convergence of the wage distributions for men and women; this has had a stabilizing effect on the overall wage distribution.

JEL Classification: J31, E24

Keywords: cross-sectional wage inequality, micro survey data, between- and within-group inequality, composition effects

\author{
Eswar S. Prasad \\ Research Department \\ International Monetary Fund \\ 700 19th Street, N.W. \\ Washington, DC 20431 \\ USA \\ Tel.: +1 (202) 623-8493 \\ Fax: +1 (202) 589-8493 \\ Email: eprasad@imf.org
}

\footnotetext{
* I am grateful to the Office for National Statistics, U.K., for providing the NES data and, in particular, to Nigel Studdard and Tiara Roy for help in using the dataset. I would also like to thank Richard Dickens and numerous colleagues and seminar participants at the IMF for helpful discussions and Stefan Hubrich for efficient research assistance. An anonymous referee provided useful comments that helped sharpen the exposition. The views expressed in this paper are my own and do not necessarily represent those of the IMF or its staff.
} 


\section{Introduction}

The patterns and determinants of changes in inequality are subjects of perennial interest to economists and policymakers alike. In particular, a vast literature has sprung up that has documented various aspects of the sharp rise in wage inequality that occurred in the U.S. in the 1980s and that has continued, although at a much lower rate, in the 1990s (e.g., Juhn, Murphy and Pierce, 1993; Buchinsky, 1994). The reasons for this rise in U.S. wage inequality have also been studied extensively, with a large body of evidence suggesting that the proximate cause can be traced to increases in the relative demand for high-skill versus low-skill labor, attributable to skill-biased technological change (e.g., Katz and Murphy, 1992; Bound and Johnson, 1992). Nevertheless, the debate on the quantitative importance of trade patterns rather than technological shifts in explaining rising wage inequality continues to be contentious (see Leamer, 2000, and Krugman, 2000, for opposing views on this matter). Whatever the reasons for the rise in wage inequality, it is undeniably a key characteristic of labor market developments in the U.S. over the last three decades and suggests that the U.S. wage structure is quite sensitive to market forces.

The U.S. is often considered the epitome of labor market "flexibility," in counterpoint to the rigid labor markets of many countries in continental Europe. Some authors have argued that, in response to skill-biased technological change that is a well-documented phenomenon across all industrial countries (Machin and Reenen, 1998), relative wages have borne much of the burden of adjustment in the U.S., resulting in rising wage inequality. In continental Europe, by contrast, institutional rigidities--including wage bargaining structures--have constrained potential increases in wage inequality; hence, labor market adjustment has occurred through significant divergences in relative unemployment and employment rates for skilled and unskilled labor (see, e.g., Siebert, 1997). The U.K. represents an interesting intermediate case of a labor market that, especially after the Thatcher-era reforms, has moved in the direction of U.S.-style flexibility. Examining the evolution of wage inequality in the U.K. is therefore of interest in terms of this broader debate as well. ${ }^{1}$

\footnotetext{
${ }^{1}$ See Prasad (2000) for a review of this literature. Nickell and Bell (1996) provide a different perspective on this debate.
} 
A number of papers have explored changes in wage inequality in the U.K. in the 1980s and early 1990s (see, e.g., Machin, 1996, 1998, and references therein). The general consensus in most of this work is that there was a significant increase in wage dispersion during the 1980s and a continued increase, although at a more moderate rate, during the early 1990s. This paper builds upon this earlier work and its first contribution is to update these results to include the latter half of the 1990s. Labor market and other institutional reforms undertaken in the Thatcher-era have been implicated by some observers as being responsible in large part for the rising wage dispersion witnessed in the 1980s and early 1990s. Hence, it is of interest to see what the longer-term effects of these reforms have been in the context of a period of strong employment growth and low unemployment, as has been witnessed in the U.K. in the latter half of the 1990s.

The paper also includes an examination of changes in within- and between-group inequality and their contributions to changes in overall inequality. A number of recently developed theoretical models have proposed that increases in between- and within-group inequality are different manifestations of the same factors, which are mostly related to technological change (see, e.g., Galor and Moav, 2000; Aghion, Hewitt and Violante, 2000). This literature has largely been based on existing stylized facts for the U.S. Hence, it is of interest to examine if other relatively "flexible" labor markets have witnessed similar patterns of changes in the different components of overall inequality.

Another important issue is whether changes in the structure of employment have influenced the evolution of wage inequality. Although wages and employment are jointly determined both at the aggregate and disaggregated levels, exogenous shifts in the structure of employment can, as an accounting matter, have a significant impact on wage inequality. An additional contribution of this paper is a careful analysis of the effects of shifts in the structure of employment - in a variety of dimensions - on changes in wage inequality.

A striking phenomenon in the U.K. labor market over the last two decades, as in many other industrial countries, is the increasing role of women in terms of labor force participation and employment. A related development is the rising share of part-time employment-largely concentrated among women - in total employment. This paper also examines the quantitative influence of these phenomena on the evolution of wage inequality. 
One of the main results in the paper is that there has been virtually no change in wage inequality in the U.K. in the latter half of the 1990s. This is in sharp contrast to the increases in inequality that were witnessed during the 1980 s and, to a lesser degree, in the first half of the 1990s. Increases in within-group inequality appear to have been the major determinant of changes in overall inequality during these earlier periods. However, both components of inequality have been essentially flat since the mid-1990s.

Marked shifts in the industrial and occupational structures of aggregate employment over the last 25 years have contributed to the total increase in U.K. wage inequality, although increases in inequality within broadly-defined industries or occupation groups still remains, in quantitative terms, the most important determinant of overall inequality. Another interesting result is that there has been a convergence of the wage distributions for men and women over this period, resulting in more stability in the overall wage distribution than for either of these groups taken separately.

Since the focus of the paper is on cross-sectional inequality, I do not examine certain other aspects of changes in inequality in the U.K. These include the relative importance of the permanent and transitory components of inequality and the related issue of mobility within the income distribution. ${ }^{2}$ In addition, given the constraints of the dataset, it is not possible to analyze broader composition effects, especially in terms of unobserved worker attributes, on the evolution of wage inequality (see, e.g., Blundell, Reed and Stoker, 1999).

\section{The Dataset}

The New Earnings Survey (NES) is an annual survey that covers roughly one percent of all employed persons in the U.K. It is conducted by the U.K. Office for National Statistics (ONS) in April of each year. The sampling frame is derived from the National Insurance records and, through their income tax records, information on employed persons from that sample are then obtained from their employers. Worker characteristics other than gender and

\footnotetext{
2 Dickens (1996) finds that increases in the permanent and temporary components of inequality are about equally responsible for the increases in male wage inequality over the period 1975-95. In subsequent work (Dickens, 1998), he finds evidence of very limited short-term (year to year) mobility within the wage distribution and also reports that wage mobility has declined from the late 1970s to the mid-1990s.
} 
age are not available in the survey; this means that issues such as the evolution of education premia cannot be analyzed using the NES. But the survey does contain a great deal of reliable information about earnings and hours as well as various occupational characteristics.

The NES has a panel element but, given problems with sample attrition over time and in light of the purposes of this study, the data are treated here as a set of repeated crosssections. Since panel attrition could be systematically correlated with certain worker characteristics, this cross-sectional approach is also helpful for maintaining the representativeness of the sample, which is important for the analysis in this paper.

Note that the NES does not contain any information on nonemployed persons, so it cannot be used to examine changes in labor force participation or other aspects of labor supply. In addition, since employers are traced through workers' income tax records, the NES undersamples individuals whose earnings fall below the income tax threshold. Nevertheless, the NES remains the most reliable source of information on earnings and occupational characteristics that are relevant for the analysis conducted here. ${ }^{3}$

The analysis in this paper is based on NES data for the period 1975-99. Nominal variables such as hourly wages and weekly earnings (both of which are reported in gross terms, before any deductions) are deflated by the RPI. ${ }^{4}$ The NES also provides very detailed information on industry and region of occupation and occupational classification. In order to present the data more concisely and also to ensure consistency over time in the classifications (which are not constant over the entire sample), I have aggregated some of these categories as described below.

Table 1 presents some summary statistics for this dataset and traces out certain patterns in the employment numbers that are relevant for interpreting changes in the wage distribution. The average number of observations per year is about 145,000 . The share of women in total employment has risen by 10 percentage points over the last 25 years, although this share has

\footnotetext{
${ }^{3}$ See Dickens (2000) for more details on the NES dataset and for a comparison of this dataset with Labour Force Survey data on low-wage workers.

${ }^{4}$ The use of the RPI-X or the private consumption deflator made little difference to the results reported in this paper.
} 
remained relatively stable since 1993. The most noticeable increase is in the share of women who are employed part-time (fewer than 35 hours per week), although the share of women who have full-time employment has also increased over the sample period.

Figure 1 breaks down total employment by industry, region and occupation group. The top left panel shows that, as in other industrial economies, the share of the manufacturing sector in total employment has declined in a gradual but steady manner since 1975 . The most striking change is that the share of service sector employment has risen from about 40 percent in the mid 1970s to over 60 percent by the late 1990s. The share of employment in public administration has remained relatively stable at about 9 percent. ${ }^{5}$

Employment headcounts may not accurately reflect inter-sectoral differences if there were significant differences in average hours worked for employees in different sectors. The lower left panel traces the evolution of an alternative measure of labor input - total hours. While there are some differences in the levels of employment shares, the patterns of changes in labor input for different sectors remain unaffected by this choice of measure.

The next two panels show the evolutions of both measures of labor input broken down by occupational group. The interesting result here is that the shares of relatively high-skill nonmanual workers have increased most sharply, from 12 percent in 1975 to over 20 percent by 1999. In addition, the share of skilled manual workers has declined while that of unskilled nonmanual workers has risen, consistent with the employment shift from industry to services shown in the previous two panels. The last two panels of Figure 1 show that employment shares have remained relatively stable across a broadly-defined grouping of regions. ${ }^{6}$

\footnotetext{
${ }^{5}$ This 4-group classification is based on 1-digit industry codes as follows: Manufacturing (metal manufacturing; textiles, leather, clothing; other manufacturing); Construction, utilities and transportation (construction; gas, electricity and water; transport and communications); Trade and services (retail and wholesale trade; financial and professional services; other services); Public administration. Excluded from this classification are agriculture, forestry and fishing; mining and quarrying; and food, drink and tobacco. Together, these 3 industries account for only about 6 percent of total employment.

${ }^{6}$ This 4-group classification is based on regional codes as follows: North (North East, North West, Merseyside); Midlands and Eastern (East Midlands, West Midlands, Eastern); London and South (London, South East, South West); and Wales and Scotland.
} 
In summary, there have been significant changes in the structure of U.K. employment that could be important for analyzing and interpreting changes in overall wage inequality. These include the rising share of women in the employed workforce, increases in the share of part-time employment, and changes in the sectoral and occupational distributions of employment.

\section{Wage Inequality}

In this section, I provide a broad empirical characterization of the evolution of crosssectional wage inequality in the U.K. during the period 1975-99. The (real) hourly wage is the wage variable used in most of the analysis since it is the appropriate measure of the unit price of labor input.

\subsection{Overall Inequality}

Wage inequality has risen quite substantially in the U.K. over the last 25 years. Figure 2 (top left panel) shows that the 90-10 percentile differential for the (log) hourly wage has increased quite sharply from 1975 to 1999 . The 75-25 percentile differential shows a more modest increase, suggesting that much of the increase in overall wage inequality has come from the top and bottom parts of the distribution rather the middle. The second panel, which restricts the sample to full-time workers shows lower levels of inequality but a similar pattern of changes in inequality. The two lower panels indicate that inequality among full-time men and women, respectively, broadly echoes the aggregate pattern. There are important differences, however, in the levels of inequality among men and women. The implications of these differences for the evolution of overall inequality are examined further below.

Figure 3 provides an alternative perspective on overall wage inequality by plotting changes in log wages at different points of the aggregate wage distribution. The top left panel shows that wage growth was significantly higher at the top percentiles of the distribution than at the lower percentiles. An interesting point to note, however, is that cumulative wage growth from 1975-99 was only about 30 percent lower for the bottom percentiles compared to the top percentiles of the distribution. Furthermore, workers near the bottom of the distribution appear to have done quite well, in relative terms, during the late-1970s. This is in sharp contrast to the 
experience of the U.S., where the differences across the distribution are more stark. In fact, in the U.S., real wage growth at the lower percentiles of the distribution has actually been negative for most of the last two decades (see Juhn, Murphy and Pierce, 1993). The other panels of Figure 3 break down the log wage changes over the three decades covered by the dataset. The dispersion of wages appears to have risen most sharply in the 1980s; the increase in the 1990s is significant but more moderate. Similar plots for men and women (not shown here) indicated that wage inequality has risen more sharply for men than it has for women. The pattern of sharpest increases in wage dispersion occurring in the 1980s is, however, true for both groups.

The top panel of Table 2 presents percentile differentials of log wages for the full economy, as well as for men and women separately. To abstract from year-to-year variation, the percentile differentials reported in this table are 3-year averages, centered on the years shown. One interesting aspect is that the increase in overall wage inequality is much lower than the corresponding increases among men and women. For instance, the change in the 90-10 differential from 1976 to 1998 is 0.37 for men and 0.36 for women, but only 0.29 overall. Changes in the corresponding 75-25 differentials are 0.25 (men), 0.26 (women) and 0.20 (all). This set of results has some interesting implications that are discussed below.

An examination of the 90-50 and 50-10 percentile differentials indicates that increases in inequality above the median of the distribution have been much greater than increases below the median. The 90-50 differential is below the 50-10 differential in 1976 but, by 1998, is well above the latter. Likewise, increases in the 75-50 differential have been much greater than those in the 50-25 differential. In other words, although increases in inequality have not been concentrated in any specific part of the distribution, there has been a relative widening of the upper end of the wage distribution.

\subsection{Within- and Between-Group Inequality}

An important question when analyzing changes in wage inequality is whether the changes are attributable to within- or between-group changes in inequality. A key feature of recent changes in inequality in the U.S. is that within-group inequality has increased very sharply as well. Whether this pattern is unique to the U.S. is of considerable interest, especially 
given the recent spate of models that attempt to model within- and between-group inequality as manifestations of the same set of forces.

The first panel of Figure 4 shows a broad measure of between-group inequality - the variance of mean log wages--across different groups. Inter-industry dispersion of wages has remained flat at a relatively low level since 1975. Inter-regional wage dispersion rose moderately during the 1980s but has since leveled off. The biggest change is in inequality among occupational groups which, by this measure, has almost doubled between 1975 and 1999, with most of the increase occurring during the 1980s. Since occupational categories are a rough measure of skill level, this result is consistent with a large body of other evidence showing a substantial increase in skill premia and, in particular, in the returns to education in the U.K. in recent decades (see, e.g., Machin, 1998).

Figure 4 (lower left panel) also shows 90-10 percentile differentials for each of four broadly-defined occupational categories. The level of inequality is much higher within the two groups of non-manual workers-high-skill managerial and professional workers and low-skill non-manual workers. A possible explanation for this result is that the unionization rate among manual workers, especially craftsmen and those employed in manufacturing, is higher and that unions have kept wages relatively more compressed for these groups. In addition, the two groups of non-manual workers span a much broader range of occupations than the two groups of manual workers. However, a more disaggregated analysis (using 8 occupational classifications) revealed a similar picture, suggesting that this latter explanation may be quantitatively less important.

The other notable feature of the results is the roughly similar evolution of within-group inequality across the four occupational groups shown here, with most of the increase in inequality occurring in the $1980 \mathrm{~s}$, followed by little increase in the $1990 \mathrm{~s}^{7}$

The third panel of Figure 4 shows 90-10 percentile differentials within each of four broadly-defined sectors. Within-group inequality is significantly higher in the trade and services sector than in the other three sectors. The time profile of inequality in the public

\footnotetext{
${ }^{7}$ The shift in inequality in 1991 for skilled manual workers partly reflects a change in coding that made it difficult to obtain a perfect match for the pre- and post-1991occupational codes.
} 
administration sector is relatively flat in the 1980s and 1990s. In the other three sectors, the evolution of inequality is quite similar and also matches the patterns in the aggregate dataparticularly the fact that most of the increase in inequality occurs in the 1980s.

A more formal approach to examine within-group inequality is to regress individual wages on observable group attributes, thereby simultaneously controlling for between-group variation in different dimensions, and to then interpret the distribution of the wage residuals as capturing within-group inequality. ${ }^{8}$ For this part of the analysis, I computed wage residuals from annual regressions of log wages on dummies for occupation, sector, region, part-time employment, and, for the full sample, a gender dummy as well. Percentile differentials of (log) hourly wage residuals are shown in the Table 3.

Within-group inequality clearly accounts for most of overall wage inequality. A comparison of the percentile differentials in this table with those in Table 2 indicates that within-group inequality accounts for about three-quarters of total inequality. Furthermore, changes in residual inequality account for a substantial fraction of the change in overall inequality - this fraction is about three-quarters for changes in the 75-25 differential (0.14/0.20) and more than four-fifths for changes in the 90-10 differential (0.24/0.29). These results are similar to those for the U.S., where within-group inequality has accounted for about two-thirds of the increase in inequality in recent decades.

Interestingly, however, it appears that the changes in within-group inequality are markedly lower for women than for men. For instance, the increase in the $90-10(75-25)$ differential from 1976 to 1998 is $0.27(0.16)$ for men but only $0.19(0.12)$ for women. Since the total change in inequality is similar for men and women (Table 2), one interpretation of this finding is that changes in the dispersion of occupational characteristics and/or sectoral preferences of employed women, rather than changes in within-group inequality, appear to account for much of the changes in wage inequality among women. This issue is discussed in more detail in the next section.

\footnotetext{
8 This approach was popularized by Juhn, Murphy and Pierce (1993). Using this technique, these authors show that, in the U.S., both within- and between-group inequality rose sharply among men during the 1980s.
} 
One other feature of the evolution of residual inequality, which is similar to that for overall inequality, is that there are greater increases above the median of the distribution than below. For instance, of the total increase from 1976 to 1998 in the 90-10 differential (0.24), about three-fourths is accounted for by the increase in the 90-50 differential (0.18). Similar results are obtained for the 75-25 differential and for men and women.

I also examined the relative contributions of different group classifications to the reduction in overall inequality. This approach provides an indication of the dimensions in which between-group inequality is more or less important in explaining overall inequality. This exercise was carried out by regressing wages on each of the sets of group dummies separately and also by experimenting with various combinations of the group dummies as regressors. The results (not reported here) showed that regressing wages on occupational dummies had the biggest impact in terms of reducing residual wage inequality. In other words, inequality between occupational classifications is the largest contributor to between-group inequality. Industry dummies and the gender dummy also have important, although much smaller, impacts and the other dummies for region and full-time employment made little difference.

\subsection{Women and the Labor Market}

One feature noted above is that women appear to have had a sizable influence on the overall wage distribution. Indeed, as in many other industrial countries, the shares of U.K. women in total employment and in the pool of labor force participants have increased markedly since the 1970s. In addition, the gender wage gap has narrowed significantly since the 1970s. In the NES data, the median wage premium for men relative to women has declined from about 42 percent in the mid-1970s to 32 percent in 1999. This decline is even sharper for full-time workers, from 35-40 percent in the mid-1970s to 21 percent in 1999. Analysis of the NES data also indicated that the narrowing of the gender wage gap appears to be a widespread phenomenon that is not limited to specific industries or occupational groups. These developments could have important implications for overall wage inequality.

To visually examine changes in the entire wage distributions for men and women and their joint effects on the overall wage distribution, I now turn to an examination of kernel density estimates of these distributions. Figure 5 shows, for selected years, kernel density 
estimates of the overall wage distribution and also those for men and women separately, with the latter distributions weighted by the respective shares of men and women in the total sample for each year. ${ }^{9}$ The striking conclusion from this set of plots is that the wage distributions for men and women have converged markedly over time, thereby partly diminishing the effects of rising within-group inequality on overall wage inequality. Reinforcing the results shown in Table 2, these plots suggest that, although the male and female wage distributions have become more unequal, the joint dynamics of these distributions have imparted some stability to the aggregate distribution.

The relative importance of women in determining the shape of the overall distribution has clearly risen sharply over the last two decades. ${ }^{10}$ Analogous kernel density plots restricted to full-time workers (not shown here) revealed a similar phenomenon of convergence of wage distributions for men and women. Although the increase in the share of women in full-time employment is smaller than in the case of total employment, it is still quantitatively quite important. In short this evidence suggests that more careful analysis of the determinants of participation decisions and occupational choices of women could be very important for understanding and interpreting changes in wage inequality as well as other aggregate labor market developments.

\footnotetext{
${ }^{9}$ This weighting procedure is similar to that employed by Fortin and Lemieux (2000). The kernel density estimates for log hourly wages were computed using an Epanechnikov kernel with bandwidth set to 0.05 . These density estimates were also computed using optimal bandwidths computed separately for each year-these bandwidths were typically in the range of 0.04-0.06. Using optimal bandwidths had little effect on the shape of the distributions. The use of a fixed bandwidth is solely to maintain consistency when comparing distributions across different years.

${ }^{10}$ Fortin and Lemieux (2000) document a similar phenomenon in the U.S. They argue that this helps reconcile two findings. One is that male wage inequality has increased sharply in the U.S. in the 1980s and, although at a slower rate, also in the 1990 s, with both within- and between-group inequality among men contributing to this increase (see, e.g., Juhn, Murphy and Pierce, 1993). The second result, documented by Lee (1999), is that the overall wage distribution in the U.S., including both men and women, was actually quite stable in the 1980s and 1990s once the effects of the decline in the real value of the minimum wage are controlled for.
} 


\section{Other Aspects of Wage Inequality}

In this section, I first examine the effects of the choice of the labor earnings variable on inequality measurement. I then explore the potential effects of changes in the structure of employment on wage inequality and also examine cohort effects on aggregate inequality.

\subsection{Earnings Inequality}

It is useful to examine if changes in patterns of hours worked have influenced the evolution of labor earnings inequality. Systematic differences in weekly hours worked for workers at different points of the wage distribution could either exacerbate or dampen the dispersion of weekly earnings relative to hourly wages. For instance, it is possible that highwage workers tend to work (and get paid for) more hours per week than low-wage workers. This would imply that wage inequality is a downward-biased measure of earnings inequality. ${ }^{11}$

The cross-sectional variance of weekly earnings can be decomposed as follows (all variables in logarithms):

$\operatorname{Var}($ Weekly Earnings $)=\operatorname{Var}($ Hourly Wage $)+\operatorname{Var}($ Weekly Hours $)+2 \operatorname{Cov}($ Wage, Hours $)$

Figure 6 shows this decomposition for each year over the period 1975-99. For the full sample (top left panel), the cross-sectional variance of weekly hours is sizable but relatively stable over this period. The covariance component is positive but small and flat. The main thing to note is that the basic time profile of changes in inequality is similar for both the wage and earnings measures - a moderate rise in inequality in the late 1970s, a sharp increase in inequality during the 1980 s, more moderate but continued increases in inequality in the early 1990s and a leveling off of inequality in the latter half of the 1990s.

For full-time workers (lower left panel), the variances of weekly earnings and hourly wages move closely together, with the variance of hours worked and the covariance component being very small and roughly off-setting each other. The same pattern holds for the samples of

\footnotetext{
11 In addition, the dispersion of annual earnings could differ from that of monthly earnings. However, the NES does not have information on annual earnings (or on the number of months of employment per year).
} 
men and women who are employed full time (middle and right lower panels). Interestingly, when all women are taken together, the variance of weekly hours is much larger (top right panel). For this group, the covariance component is positive and rises slightly over the full sample. Thus, the increase in earnings inequality among all women is slightly greater than the increase in wage inequality. This difference could become more important in the future if the share of women in employment continues to increase.

Overall, the evidence in this sub-section suggests that, over the last 25 years, the patterns of changes in inequality have been similar irrespective of whether the wage or earnings measure is used.

\subsection{Effects of Shifts in the Structure of Employment on Wage Inequality}

As shown in Section 2, there have been marked changes in the structure of employment in the U.K. over the last 25 years - in terms of occupational as well as sectoral distributions of employment. These shifts could by themselves generate apparent changes in inequality even if there were no changes in the underlying wage structure. For instance, setting aside general equilibrium considerations for the nonce, reallocation of workers from one sector to another could change inequality through two channels - a between-group effect (if mean wages in the two sectors were different) and a within-group effect (if within-group inequality was different in the two sectors).

To take a more concrete example, the total variance of wages in a year can be decomposed into within- and between-industry components as follows:

$$
\sigma_{t}^{2}=\sum_{j} s_{j t} \sigma_{j t}^{2}+\sum_{j} s_{j t}\left(w_{j t}-\bar{w}_{t}\right)^{2}
$$

where $\sigma_{t}^{2}$ is the cross-sectional variance of log hourly wages, $s_{j t}$ is the employment share of sector $j, \sigma_{j t}^{2}$ is the within-industry variance of wages, $w_{j t}$ is the mean sectoral wage, $\bar{w}_{t}$ is the mean wage in the sample and the subscript $t$ is a time index. Using this formula, the change in variance over time can be decomposed into changes attributable to within- and between- 
industry variance as well as composition effects within and between industries. A similar decomposition can be done based on any group characteristic.

Table 4 presents the results for these decompositions for different group characteristics and, where appropriate, also separately for men and women. The results reported in this table include full-time and part-time workers. Restricting the sample to full-time workers made virtually no qualitative difference to any of the results discussed here.

The first panel of this table shows that, for all workers, the total change in variance is attributable almost entirely to two factors: the change in within-industry variance and, to a lesser extent, the composition effect of a shift towards industries with higher within-group inequality. As noted in the analysis of inequality within industries, there is a higher level of inequality in services (Figure 4), which has had a rising employment share (Figure 1), compared to manufacturing, which has relatively lower inequality and a declining share of employment. The industry composition effect appears to be stronger for men than for women.

For the second panel, I recomputed the variance decompositions for occupational classifications. Interestingly, although within-group inequality is the most important factor, the composition effects, both within- and between-group, as well as the between-group changes in variance are also important factors in explaining the increase in total wage variance. These results are consistent with some features of the data documented earlier-widening inequality among occupational groups, higher inequality among high-skill as well as low-skill nonmanual workers and the rising employment share of non-manual workers at all skill levels. Interestingly the contribution of changes in between-group inequality (fourth column) appear to be largest for women. Restricting the sample to full-time workers marginally attenuated this feature of the results but, in qualitative terms, none of the results in this table was affected by the exclusion of part-time workers.

The third panel of Table 4 indicates a slight widening of inter-regional wage dispersion but most of the increase in total wage variance appears attributable to within-region increases in the variance of wages. The next panel shows that changes in the composition of employment from full-time to part-time work have had only a small effect on overall inequality - most of the increase in inequality is attributable to inequality changes within these categories of employment. 
Consistent with the evidence presented in earlier sections, the bottom panel of Table 4 shows that increases in within-group inequality for men and women have been partly offset by two factors. The first is the within-group composition effect, i.e., the increase in the share of women, who have lower within-group inequality, in total employment. In addition, the between-group component of total variance has declined markedly, in line with the narrowing of the gender wage gap discussed earlier.

\subsection{Inequality Within and Between Cohorts}

Wage inequality tends to rise over the life cycle due to the accumulated effects of individual-specific productivity shocks as well as the rising dispersion of information about worker attributes available from employment histories and other sources. Thus, changes in relative cohort sizes could influence overall wage inequality even if inequality were to evolve in an identical fashion over the life cycle for every cohort. Alternatively, changes in the dispersion of attributes (either observed or unobserved) among recent cohorts could account for increases in overall inequality even though within-cohort inequality may remain unchanged for older cohorts. Disentangling these age and cohort effects from time effects is, however, a complicated matter.

Table 5 shows inequality over time for specific synthetic birth-year cohorts. ${ }^{12}$ Although it is not possible to identify age and cohort effects separately, there are some patterns worth noting. In general, there appears to be a pattern of increase over time in within-cohort inequality, as measured by the $90-10$ and $75-25$ percentile differentials, although inequality among older workers (those born before 1930) is relatively flat even in the 1980s. The changes over time appear much greater for younger cohorts, suggesting that the effects of idiosyncratic productivity shocks and related factors on within-cohort inequality tend to occur relatively early in the life cycle. Furthermore, reading down any of the columns in the table, which is a way of getting at age (or experience) effects, inequality across cohorts appears to have a hump-

\footnotetext{
${ }^{12}$ The results reported in Table 5 are for 5-year cohorts and are based on the full sample that includes both fulltime and part-time workers. Results based on 10-year cohorts or on a restricted sample limited to full-time workers made little difference to the main conclusions.
} 
shaped pattern. This is suggestive of a nonlinear relationship between age and inequality, with within-cohort inequality initially rising quite sharply and then declining marginally towards the end of the life cycle of workers in a given cohort. ${ }^{13}$

Although it is not possible to separate out inequality growth over time from inequality growth across cohort and age groups, looking at average changes in inequality growth over time for both cohorts and age groups could help characterize the evolution of the residual time effects (see Juhn, Murphy and Pierce, 1993). The bottom panel of Table 5 shows that average inequality changes across cohorts and experience groups were moderate in the late 1970s, rose sharply in the 1980s and then fell to a lower level in the 1990s. The time effects on inequality indicated by this exercise appear to be consistent with the patterns of changes in aggregate inequality discussed thus far. In other words, although changes in within-cohort inequality do appear quantitatively quite large in this sample, cohort and age effects do not seem to be the proximate determinants of the changes in overall inequality over the period 1975-99. ${ }^{14}$

\section{Conclusions}

Using micro data from the New Earnings Survey, this paper has examined the evolution of wage inequality in the U.K. over the period 1975-99. One interesting finding is that, after sharp increases in the 1980s and continued but moderate increases in the early 1990s, wage inequality has remained essentially unchanged during the latter half of the 1990s. The dispersion of hourly wages and weekly earnings show very similar patterns. Furthermore, much of the increase in cross-sectional inequality is attributable to increases in within-group inequality.

There have been significant shifts in the industrial and occupational structures of U.K. employment over the last 25 years. These changes have had quantitatively important, but not dominant, effects on the wage structure. In addition, there has been a marked convergence of

\footnotetext{
13 Self-selection into retirement probably accounts for the decline in inequality among older workers.

${ }^{14}$ Using the more limited panel sub-sample from the NES, Dickens (2000) provides a careful analysis of cohort effects on male wage inequality in the U.K. during the period 1975-95.
} 
the wage distributions for men and women. This phenomenon, along with the rising share of women in total employment, has moderated the increase in overall inequality.

These results indicate many similarities but also some important differences relative to developments in wage inequality in the U.S. The pattern of sharp increases in wage inequality in the 1980s and a more moderate increase in the 1990s is similar to the pattern in the U.S. But, in terms of degree, increases in wage inequality in the U.K. have been much lower than in the U.S. The contributions of increases in residual (within-group) wage inequality to increases in overall wage inequality have been even higher in the U.K. than in the U.S. The moderating influence of the convergence of the wage distributions for men and women on the evolution of overall wage inequality is similar in both countries.

Given the exalted status of the U.S. labor market as the standard that all other labor markets are measured by, the similarity (although not quite in degree) of the increases in wage inequality in the U.S. and the U.K. over the last two and a half decades suggests that the U.K. has a rather "flexible" labor market. By itself, however, the increase in wage inequality merits no such approbation. What matters is the joint outcome in terms of both quantities (employment) and prices (wages). ${ }^{15}$ On this metric, the U.K. labor market does in fact come out well since the increase in wage inequality has coincided with strong employment performance, with employment ratios increasing for all skill levels and independent of observed skill attributes. The evidence for rising dispersion of wages across occupational categories, which is a rough proxy for skill levels, is consistent with the notion of skill-biased technological change. Hence, future changes in inequality could hinge on the relative supply of skilled and unskilled workers. Influencing this relative supply, through the educational system and other means, remains an avenue for policy measures to affect wage inequality as well as the overall growth potential of the economy.

\footnotetext{
15 See Prasad (2000) for more discussion of this point and for an interesting contrast provided by the German experience.
} 


\section{References}

Aghion, Philippe, Peter Howitt and Gianluca Violante (2000) "General Purpose Technology and Within-Group Inequality,” Manuscript, University College, London.

Blundell, Richard, H. Reed and Thomas Stoker (1999) "Interpreting Movements in Average Male Earnings: The Role of Labor Market Participation,” IFS Working Paper No. 99/13 (London, U.K.: Institute for Fiscal Studies).

Bound, John and George Johnson (1992) "Changes in the Structure of Wages During the 1980s: An Evaluation of Alternative Explanations," American Economic Review, Vol. 82, pp. 371-92.

Buchinsky, Moshe (1994) "Changes in the U.S. Wage Structure 1963-1987: Application of Quantile Regression,” Econometrica, Vol. 62, pp. 405-58.

Dickens, Richard (2000) “The Evolution of Individual Male Earnings in Great Britain," The Economic Journal, Vol. 110, pp. 27-49.

Dickens, Richard (2000) "Caught in a Trap? Wage Mobility in Great Britain: 1975-1994," Economica, Vol. 67, pp. 477-497.

Fortin, Nicole M. and Thomas Lemieux (2000) “Are Women's Wage Gains Men's Losses? A Distributional Test," AER Papers and Proceedings, Vol. 90, pp. 456-460.

Galor, Oded, and Omer Moav (2000) "Ability-Biased Technological Transition, Wage Inequality, and Economic Growth," Quarterly Journal of Economics, Vol. 115, pp. 46997.

Gottschalk, Peter, and Timothy M. Smeeding (1997) "Cross-National Comparisons of Earnings and Income Inequality," Journal of Economic Literature, Vol. 35, pp. 633-687.

Gregg, Paul and Stephen Machin (1994) "Is the Rise in U.K. Inequality Different," in The U.K. Labor Market: Comparative Aspects and Institutional Developments, edited by Ray Barrell (Glasgow, U.K.: Bell and Bain Ltd.).

Juhn, Chinhui, Kevin M. Murphy, and Brooks Pierce (1993) "Wage Inequality and the Rise in Returns to Skill,” Journal of Political Economy, Vol. 101, pp. 410-442.

Katz, Lawrence F., and Kevin M. Murphy (1992) "Changes in the Wage Structure: Supply and Demand Factors," Quarterly Journal of Economics, Vol. 107, pp. 35-78.

Krugman, Paul R. (2000) “Technology, Trade and Factor Prices,” Journal of International Economics, Vol. 50, pp. 51-71. 
Leamer, Edward (2000) "What's the Use of Factor Contents?" Journal of International Economics, Vol. 50, pp. 17-49.

Lee, David S. (1999) "Wage Inequality in the United States During the 1980s: Rising Dispersion or Falling Minimum Wage?” Quarterly Journal of Economics, Vol. 114, pp. 977-1023.

Machin, Stephen, and John Van Reenen (1998) "Technology and Changes in Skill Structure: Evidence from Seven OECD Countries," Quarterly Journal of Economics, Vol. 113, pp. 1215-1244.

Machin, Stephen (1996) "Wage Inequality in the U.K.," Oxford Review of Economic Policy, Vol. 12, pp. 47-64.

Machin, Stephen (1998) "Recent Shifts in Wage Inequality and the Wage Returns to Education in Britain," National Institute Economic Review, pp. 87-95.

Nickell, Stephen, and Brian Bell (1996) "Changes in the Distribution of Wages and Unemployment in OECD Countries," American Economic Review, Vol. 86, pp. 302-308.

Prasad, Eswar S. (2000) "The Unbearable Stability of the German Wage Structure: Evidence and Interpretation," IMF Working Paper No. 00/22.

Siebert, Horst (1997) "Labor Market Rigidities: At the Root of Unemployment in Europe," Journal of Economic Perspectives, Vol. 11, pp. 37-54. 
Table 1. Summary Statistics for NES Wage Analysis Sample

\begin{tabular}{|c|c|c|c|c|c|c|}
\hline \multirow[b]{3}{*}{ Year } & \multirow{3}{*}{$\begin{array}{c}\text { Number of } \\
\text { Observations }\end{array}$} & \multirow{3}{*}{$\begin{array}{l}\text { Median Real } \\
\text { Hourly Wage }\end{array}$} & \multicolumn{4}{|c|}{ Employment Shares } \\
\hline & & & \multirow[b]{2}{*}{ Men } & \multirow[b]{2}{*}{ Full-time } & \multicolumn{2}{|c|}{ Part-time } \\
\hline & & & & & Men & Women \\
\hline 1975 & 139941 & 1.55 & 0.64 & 0.85 & 0.02 & 0.12 \\
\hline 1976 & 150801 & 1.58 & 0.63 & 0.84 & 0.03 & 0.14 \\
\hline 1977 & 153118 & 1.52 & 0.62 & 0.84 & 0.02 & 0.13 \\
\hline 1978 & 152653 & 1.54 & 0.62 & 0.84 & 0.02 & 0.13 \\
\hline 1979 & 151367 & 1.54 & 0.61 & 0.84 & 0.02 & 0.14 \\
\hline 1980 & 144589 & 1.61 & 0.61 & 0.83 & 0.02 & 0.14 \\
\hline 1981 & 150951 & 1.60 & 0.60 & 0.84 & 0.02 & 0.14 \\
\hline 1982 & 150394 & 1.61 & 0.60 & 0.84 & 0.02 & 0.14 \\
\hline 1983 & 141003 & 1.67 & 0.60 & 0.83 & 0.02 & 0.14 \\
\hline 1984 & 138329 & 1.69 & 0.59 & 0.83 & 0.02 & 0.14 \\
\hline 1985 & 135779 & 1.69 & 0.59 & 0.83 & 0.03 & 0.14 \\
\hline 1986 & 140881 & 1.73 & 0.59 & 0.83 & 0.03 & 0.14 \\
\hline 1987 & 143021 & 1.75 & 0.58 & 0.84 & 0.03 & 0.14 \\
\hline 1988 & 150187 & 1.78 & 0.58 & 0.83 & 0.03 & 0.14 \\
\hline 1989 & 148587 & 1.80 & 0.57 & 0.84 & 0.02 & 0.14 \\
\hline 1990 & 151789 & 1.80 & 0.56 & 0.84 & 0.02 & 0.14 \\
\hline 1991 & 151797 & 1.83 & 0.55 & 0.83 & 0.02 & 0.15 \\
\hline 1992 & 147232 & 1.86 & 0.55 & 0.82 & 0.02 & 0.15 \\
\hline 1993 & 141473 & 1.88 & 0.54 & 0.82 & 0.03 & 0.16 \\
\hline 1994 & 144199 & 1.88 & 0.54 & 0.81 & 0.03 & 0.16 \\
\hline 1995 & 139798 & 1.88 & 0.54 & 0.78 & 0.04 & 0.19 \\
\hline 1996 & 140318 & 1.89 & 0.54 & 0.78 & 0.04 & 0.19 \\
\hline 1997 & 134076 & 1.90 & 0.53 & 0.77 & 0.04 & 0.19 \\
\hline 1998 & 136314 & 1.90 & 0.54 & 0.77 & 0.04 & 0.20 \\
\hline 1999 & 137805 & 1.93 & 0.54 & 0.77 & 0.04 & 0.19 \\
\hline
\end{tabular}

Note: All employment shares shown in this table are relative to total employment. Nominal hourly wages are deflated by the Retail Price Index (RPI). 
Table 2. Measures of Wage Inequality: Percentile Differentials

\begin{tabular}{|c|c|c|c|c|c|c|}
\hline $\begin{array}{c}\text { Percentile } \\
\text { Differential: }\end{array}$ & $90-10$ & $90-50$ & $50-10$ & $75-25$ & $75-50$ & $50-25$ \\
\hline \multicolumn{7}{|c|}{ A. All Workers } \\
\hline 1976 & 1.04 & 0.56 & 0.49 & 0.52 & 0.27 & 0.26 \\
\hline 1980 & 1.08 & 0.59 & 0.48 & 0.55 & 0.29 & 0.27 \\
\hline 1990 & 1.24 & 0.70 & 0.54 & 0.66 & 0.35 & 0.31 \\
\hline 1998 & 1.33 & 0.75 & 0.57 & 0.72 & 0.39 & 0.33 \\
\hline \multicolumn{7}{|c|}{ B. Men } \\
\hline 1976 & 0.95 & 0.53 & 0.42 & 0.45 & 0.24 & 0.21 \\
\hline 1980 & 0.99 & 0.56 & 0.43 & 0.49 & 0.26 & 0.23 \\
\hline 1990 & 1.20 & 0.68 & 0.52 & 0.62 & 0.33 & 0.29 \\
\hline 1998 & 1.32 & 0.74 & 0.58 & 0.70 & 0.37 & 0.33 \\
\hline \multicolumn{7}{|c|}{ C. Women } \\
\hline 1976 & 0.87 & 0.50 & 0.38 & 0.41 & 0.22 & 0.19 \\
\hline 1980 & 0.86 & 0.53 & 0.33 & 0.44 & 0.24 & 0.20 \\
\hline 1990 & 1.12 & 0.68 & 0.44 & 0.59 & 0.33 & 0.26 \\
\hline 1998 & 1.23 & 0.73 & 0.50 & 0.67 & 0.37 & 0.29 \\
\hline
\end{tabular}

Notes: Percentile differentials are computed for each year from the cross-sectional distribution of $(\log )$ hourly wages. The reported differentials are three-year averages centered on the years shown above. Standard errors for these differentials were all below 0.01 . 
Table 3. Measures of Residual Wage Inequality: Percentile Differentials

\begin{tabular}{|c|c|c|c|c|c|c|}
\hline $\begin{array}{c}\text { Percentile } \\
\text { Differential: }\end{array}$ & $90-10$ & $90-50$ & $50-10$ & $75-25$ & $75-50$ & $50-25$ \\
\hline \multicolumn{7}{|c|}{ A. All Workers } \\
\hline 1976 & 0.78 & 0.38 & 0.40 & 0.37 & 0.18 & 0.19 \\
\hline 1980 & 0.78 & 0.40 & 0.38 & 0.37 & 0.19 & 0.18 \\
\hline 1990 & 0.91 & 0.49 & 0.42 & 0.45 & 0.24 & 0.22 \\
\hline 1998 & 1.02 & 0.56 & 0.46 & 0.51 & 0.27 & 0.24 \\
\hline \multicolumn{7}{|c|}{ B. Men } \\
\hline 1976 & 0.76 & 0.36 & 0.40 & 0.36 & 0.18 & 0.18 \\
\hline 1980 & 0.78 & 0.38 & 0.40 & 0.37 & 0.19 & 0.19 \\
\hline 1990 & 0.91 & 0.46 & 0.45 & 0.45 & 0.23 & 0.23 \\
\hline 1998 & 1.03 & 0.54 & 0.49 & 0.52 & 0.27 & 0.26 \\
\hline \multicolumn{7}{|c|}{ C. Women } \\
\hline 1976 & 0.80 & 0.41 & 0.39 & 0.37 & 0.18 & 0.19 \\
\hline 1980 & 0.76 & 0.43 & 0.33 & 0.36 & 0.19 & 0.17 \\
\hline 1990 & 0.92 & 0.53 & 0.39 & 0.44 & 0.24 & 0.20 \\
\hline 1998 & 0.99 & 0.57 & 0.42 & 0.49 & 0.27 & 0.21 \\
\hline
\end{tabular}

Notes: Percentile differentials are computed for each year from the cross-sectional distribution of wage residuals. Wage residuals are from annual regressions of log hourly wages on a full set of dummies for industry, occupation, region, full-time employment and, in panel A, for gender. The reported differentials are three-year averages centered on the years shown above. Standard errors for these differentials were all smaller than 0.01 . 
Table 4. Effects of Shifts in the Employment Structure on Changes in Wage Inequality (Variance Decomposition)

\begin{tabular}{|c|c|c|c|c|c|}
\hline & \multirow{2}{*}{$\begin{array}{c}\text { Total Change } \\
\text { in Variance } \\
1975-99\end{array}$} & \multicolumn{2}{|c|}{ Within Group } & \multicolumn{2}{|c|}{ Between Group } \\
\hline & & $\begin{array}{l}\text { Change in } \\
\text { Variance }\end{array}$ & $\begin{array}{l}\text { Composition } \\
\text { Effect }\end{array}$ & $\begin{array}{l}\text { Change in } \\
\text { Variance }\end{array}$ & $\begin{array}{c}\text { Composition } \\
\text { Effect }\end{array}$ \\
\hline \multicolumn{6}{|l|}{ Industry } \\
\hline All Workers & 8.66 & 6.33 & 2.85 & -0.24 & -0.27 \\
\hline Men & 11.91 & 7.53 & 4.37 & 0.30 & -0.29 \\
\hline Women & 8.59 & 7.53 & 1.30 & -0.08 & -0.16 \\
\hline \multicolumn{6}{|l|}{ Occupation } \\
\hline All Workers & 8.66 & 3.54 & 1.62 & 2.00 & 1.49 \\
\hline Men & 11.91 & 4.93 & 2.24 & 2.88 & 1.86 \\
\hline Women & 8.59 & 2.56 & 1.29 & 4.03 & 0.71 \\
\hline \multicolumn{6}{|l|}{ Region } \\
\hline All Workers & 8.66 & 7.95 & -0.03 & 0.86 & -0.11 \\
\hline Men & 11.91 & 11.19 & 0.02 & 0.78 & -0.08 \\
\hline Women & 8.59 & 8.04 & -0.10 & 0.82 & -0.17 \\
\hline \multicolumn{6}{|c|}{ Employment Status } \\
\hline All Workers & 8.66 & 7.43 & 0.27 & 0.66 & 0.31 \\
\hline Men & 11.91 & 11.16 & 0.63 & 0.02 & 0.10 \\
\hline Women & 8.59 & 7.56 & 0.29 & 0.71 & 0.03 \\
\hline \multicolumn{6}{|l|}{ Gender } \\
\hline All Workers & 8.66 & 10.71 & -0.54 & -1.57 & 0.05 \\
\hline
\end{tabular}

Note: The total change in the variance of log wages is decomposed into four components based on the first-differenced version of equation (2) in the paper. All numbers in this table have been multiplied by 100 . 
Table 5. Inequality Within Cohorts

\begin{tabular}{|c|c|c|c|c|c|c|c|c|}
\hline \multirow[t]{2}{*}{ Year of Birth } & \multicolumn{4}{|c|}{ 90-10 differential } & \multicolumn{4}{|c|}{ 75-25 differential } \\
\hline & 1975 & 1980 & 1990 & 1999 & 1975 & 1980 & 1990 & 1999 \\
\hline 1911-15 & 0.89 & 0.87 & $\ldots$ & $\ldots$ & 0.45 & 0.43 & $\ldots$ & $\ldots$ \\
\hline $1916-20$ & 1.01 & 0.98 & 0.91 & $\ldots$ & 0.50 & 0.48 & 0.46 & $\ldots$ \\
\hline $1921-25$ & 1.03 & 1.04 & 1.06 & 1.09 & 0.52 & 0.51 & 0.52 & 0.49 \\
\hline $1926-30$ & 1.09 & 1.11 & 1.09 & 1.01 & 0.55 & 0.55 & 0.55 & 0.47 \\
\hline $1931-35$ & 1.10 & 1.13 & 1.25 & 1.22 & 0.56 & 0.57 & 0.63 & 0.59 \\
\hline 1936-40 & 1.08 & 1.14 & 1.32 & 1.23 & 0.57 & 0.59 & 0.69 & 0.62 \\
\hline $1941-45$ & 1.04 & 1.13 & 1.35 & 1.35 & 0.52 & 0.60 & 0.73 & 0.70 \\
\hline $1946-50$ & 0.88 & 1.06 & 1.34 & 1.39 & 0.45 & 0.54 & 0.75 & 0.78 \\
\hline $1951-55$ & 0.75 & 0.87 & 1.31 & 1.41 & 0.39 & 0.45 & 0.73 & 0.80 \\
\hline $1956-60$ & 0.78 & 0.72 & 1.21 & 1.36 & 0.41 & 0.38 & 0.65 & 0.76 \\
\hline $1961-65$ & $\ldots$ & 0.67 & 1.05 & 1.32 & $\ldots$ & 0.32 & 0.56 & 0.71 \\
\hline $1966-70$ & $\ldots$ & $\ldots$ & 0.87 & 1.22 & $\ldots$ & $\ldots$ & 0.47 & 0.65 \\
\hline $1971-75$ & $\ldots$ & $\ldots$ & 0.72 & 1.07 & $\ldots$ & $\ldots$ & 0.38 & 0.58 \\
\hline $1976-80$ & $\ldots$ & $\ldots$ & $\ldots$ & 0.84 & $\ldots$ & $\ldots$ & $\ldots$ & 0.45 \\
\hline \multirow[t]{3}{*}{$>1980$} & $\ldots$ & $\ldots$ & $\ldots$ & 0.60 & $\ldots$ & $\ldots$ & $\ldots$ & 0.29 \\
\hline & & \multicolumn{3}{|c|}{ 90-10 differential } & & \multicolumn{3}{|c|}{ 75-25 differential } \\
\hline & & $1975-80$ & $1980-90$ & $1990-99$ & & $1975-80$ & $1980-90$ & $1990-99$ \\
\hline \multicolumn{2}{|l|}{$\begin{array}{l}\text { Average change } \\
\text { within cohorts: }\end{array}$} & 0.04 & 0.20 & 0.10 & & 0.02 & 0.13 & 0.04 \\
\hline \multicolumn{2}{|c|}{$\begin{array}{l}\text { Average change } \\
\text { within experience groups: }\end{array}$} & 0.02 & 0.19 & 0.09 & & 0.01 & 0.12 & 0.04 \\
\hline
\end{tabular}

Notes: Percentile differentials are computed based on the distribution of $(\log )$ hourly wages for all observations in a given cell. Results are reported only for cells with at least 100 observations. Sample includes all workers (including part-time). 

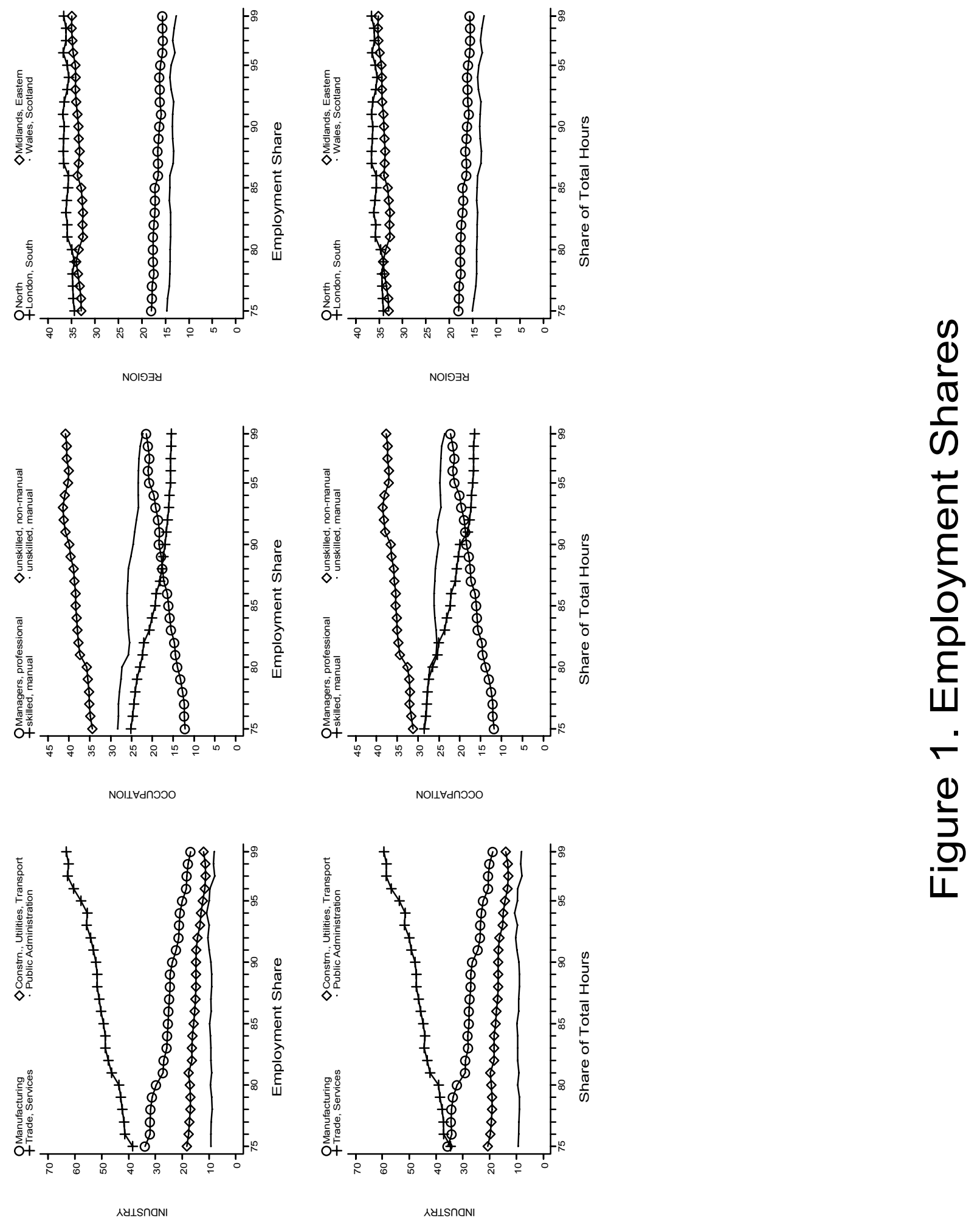

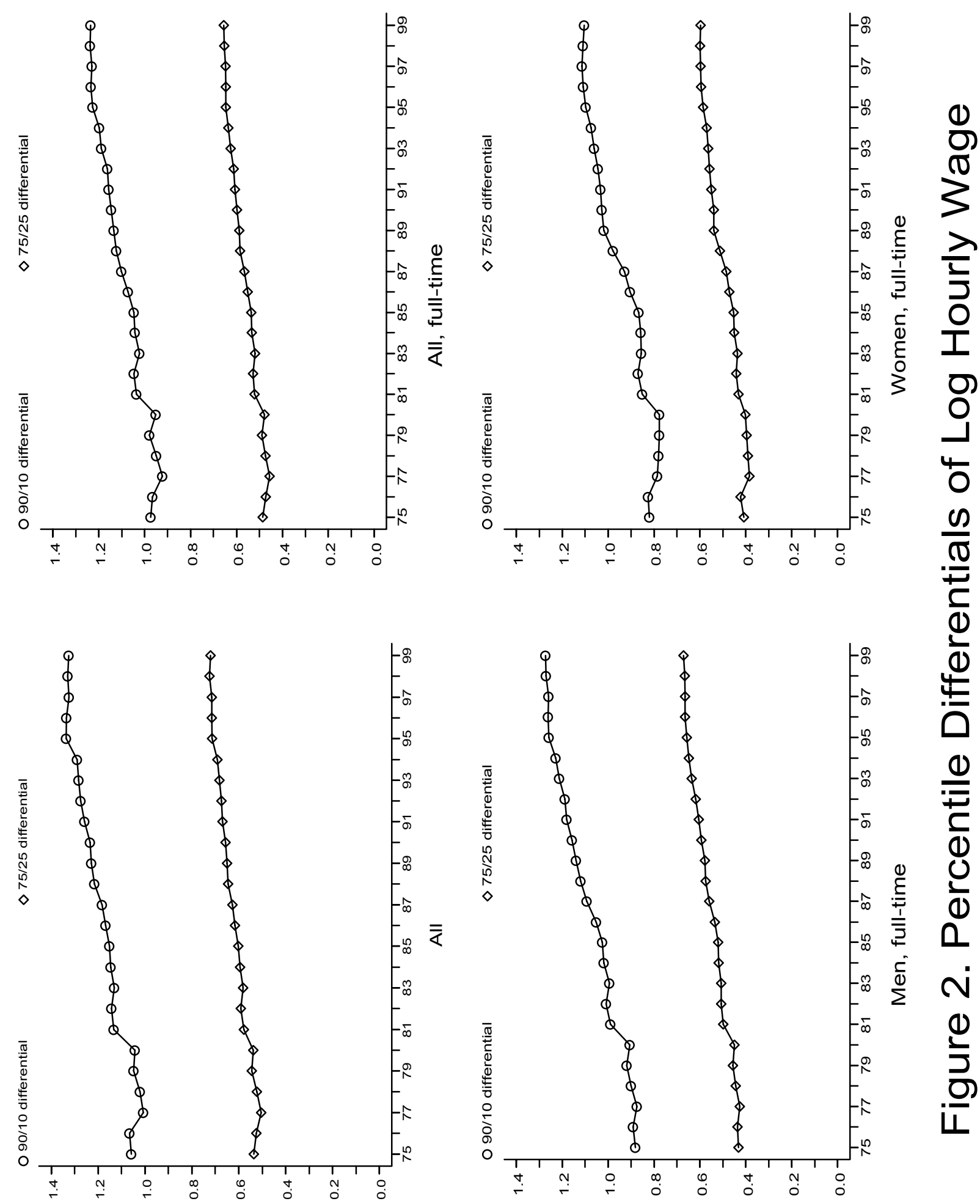

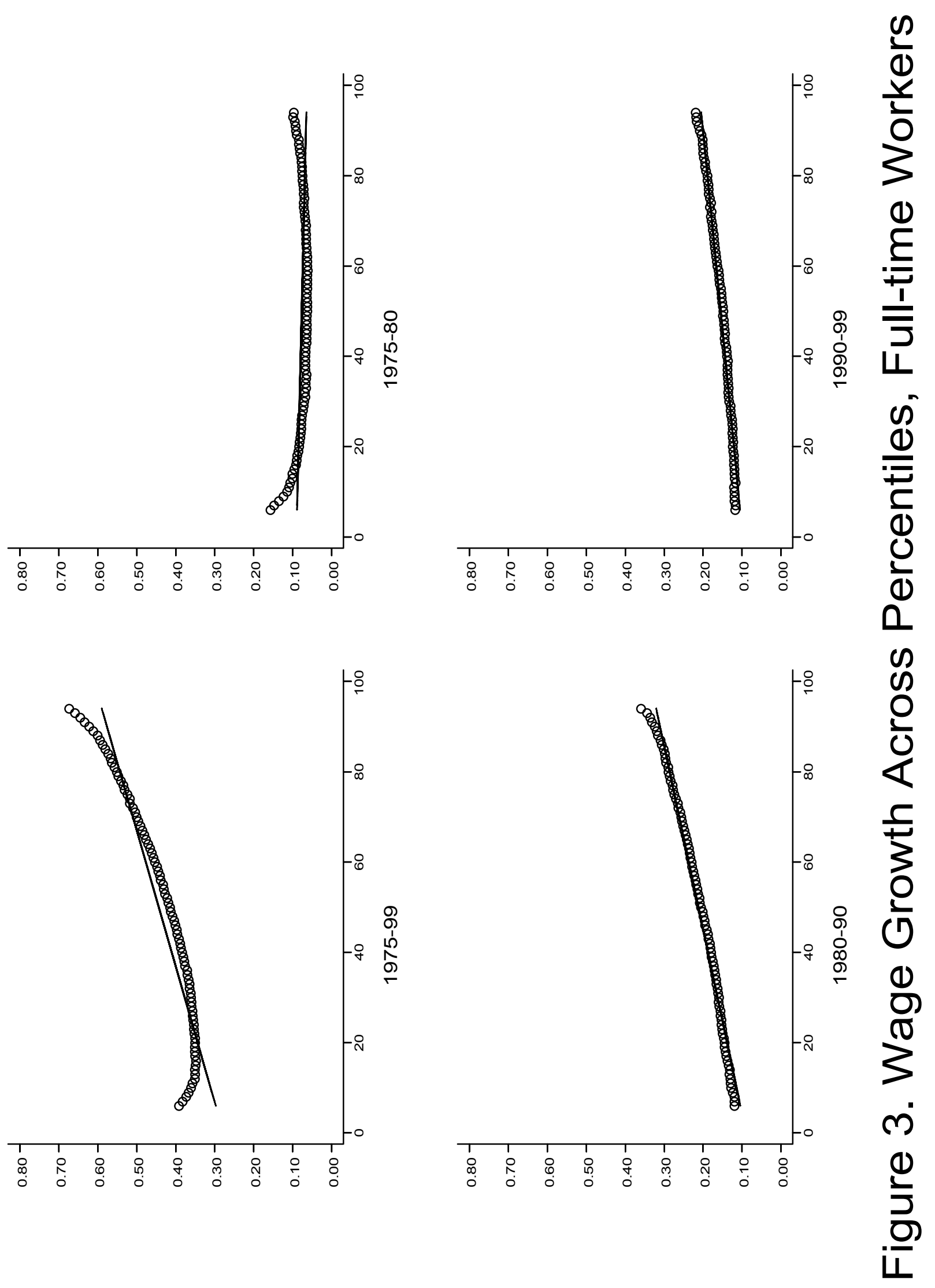


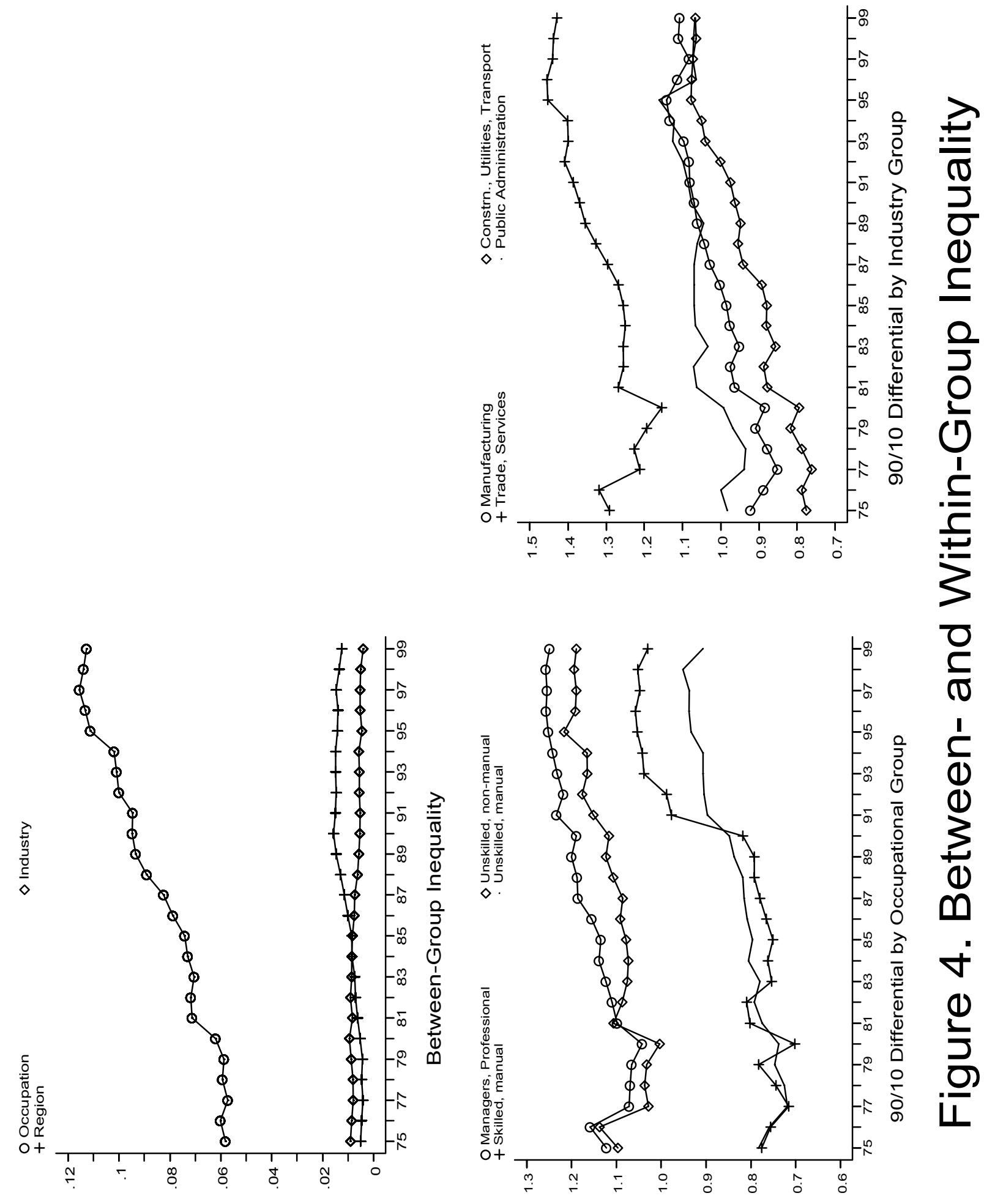



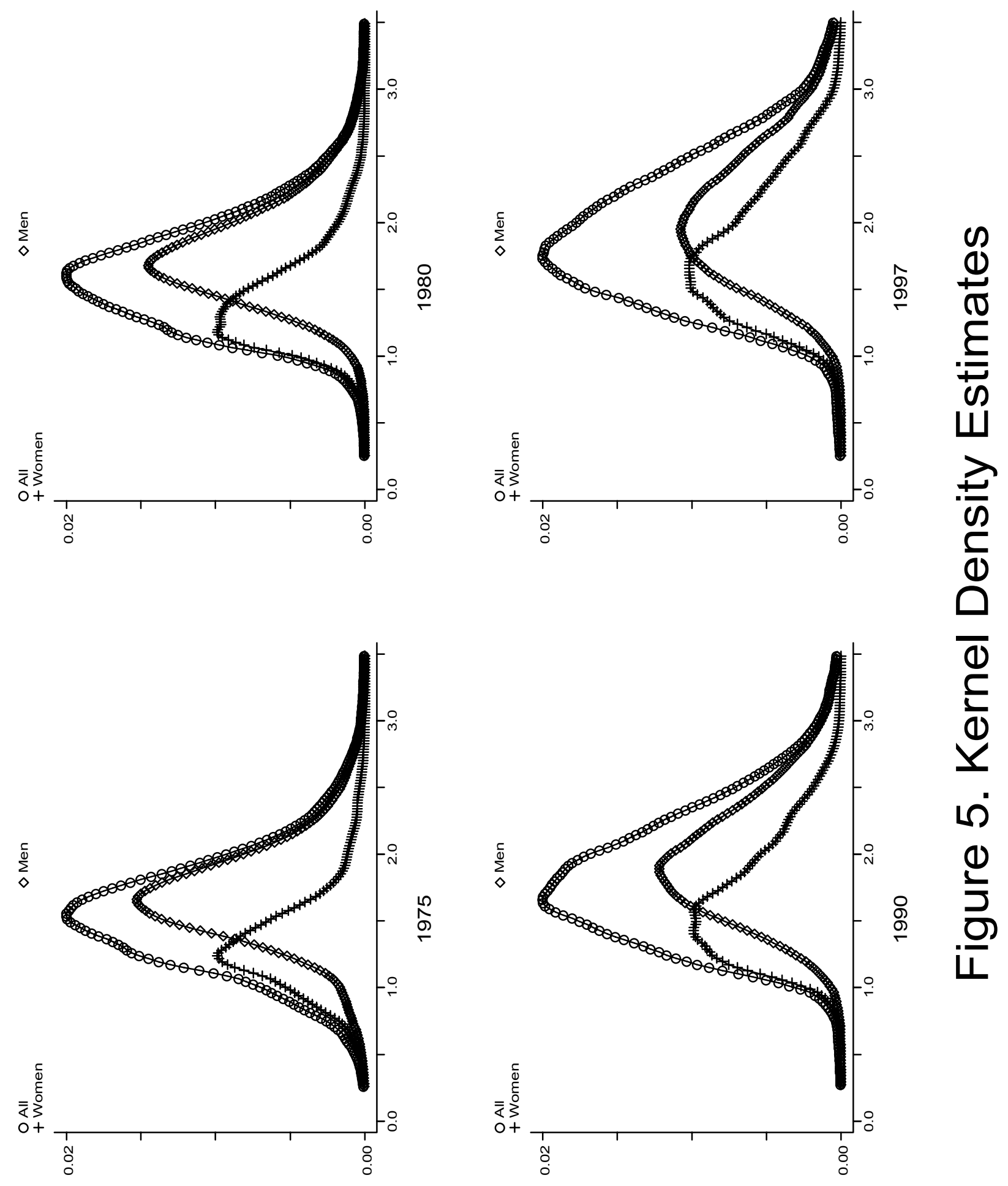

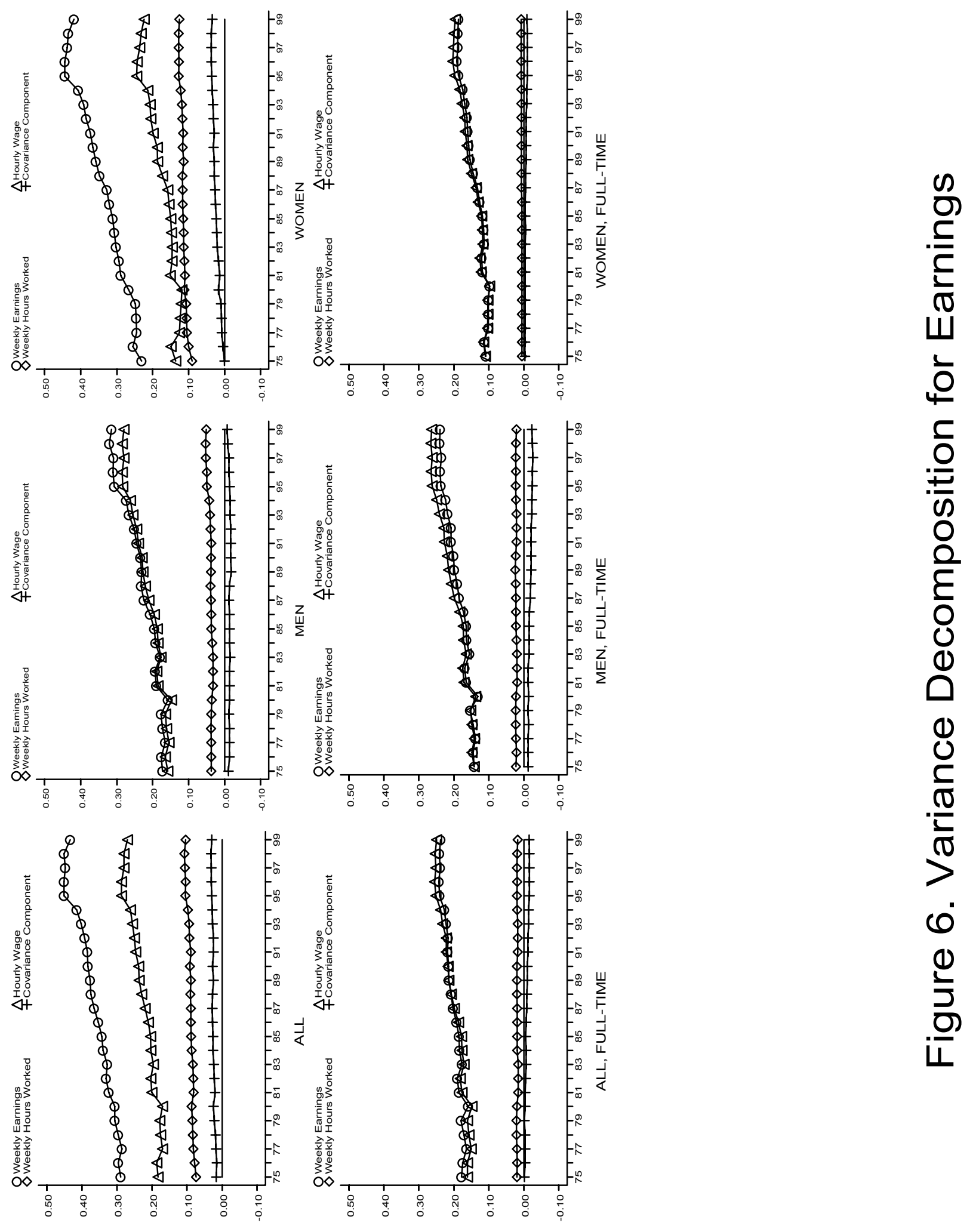


\section{IZA Discussion Papers}

\begin{tabular}{|c|c|c|c|c|}
\hline No. & Author(s) & Title & Area & Date \\
\hline 493 & $\begin{array}{l}\text { R. M. Leontaridi } \\
\text { M. E. Ward }\end{array}$ & $\begin{array}{l}\text { Work-Related Stress, Quitting Intentions and } \\
\text { Absenteeism }\end{array}$ & 5 & $05 / 02$ \\
\hline 494 & $\begin{array}{l}\text { J. Wagner } \\
\text { R. Sternberg }\end{array}$ & $\begin{array}{l}\text { The Role of the Regional Milieu for the Decision } \\
\text { to Start a New Firm: Empirical Evidence for } \\
\text { Germany }\end{array}$ & 1 & $05 / 02$ \\
\hline 495 & $\begin{array}{l}\text { J. T. Addison } \\
\text { L. Bellmann } \\
\text { C. Schnabel } \\
\text { J. Wagner }\end{array}$ & $\begin{array}{l}\text { German Works Councils Old and New: } \\
\text { Incidence, Coverage and Determinants }\end{array}$ & 3 & $05 / 02$ \\
\hline 496 & $\begin{array}{l}\text { M. P. Keane } \\
\text { E. S. Prasad }\end{array}$ & $\begin{array}{l}\text { Changes in the Structure of Earnings During the } \\
\text { Polish Transition }\end{array}$ & 4 & $05 / 02$ \\
\hline 497 & D. Gatti & $\begin{array}{l}\text { European Integration and Employment: } \\
\text { A New Role for Active Fiscal Policies? }\end{array}$ & 2 & $05 / 02$ \\
\hline 498 & $\begin{array}{l}\text { P. Frijters } \\
\text { J. P. Haisken-DeNew } \\
\text { M. A. Shields }\end{array}$ & $\begin{array}{l}\text { Individual Rationality and Learning: Welfare } \\
\text { Expectations in East Germany Post- } \\
\text { Reunification }\end{array}$ & 6 & $05 / 02$ \\
\hline 499 & $\begin{array}{l}\text { G. A. Pfann } \\
\text { H. van Kranenburg }\end{array}$ & $\begin{array}{l}\text { Tax Policy, Location Choices, and Market } \\
\text { Structure }\end{array}$ & 6 & 05/02 \\
\hline 500 & D. A. Jaeger & $\begin{array}{l}\text { Estimating the Returns to Education Using the } \\
\text { Newest Current Population Survey Education } \\
\text { Questions }\end{array}$ & 6 & 05/02 \\
\hline 501 & $\begin{array}{l}\text { C. Dustmann } \\
\text { N. Rajah } \\
\text { A. van Soest }\end{array}$ & Class Size, Education, and Wages & 5 & $05 / 02$ \\
\hline 502 & $\begin{array}{l}\text { B. R. Chiswick } \\
\text { Y. L. Lee } \\
\text { P. W. Miller }\end{array}$ & $\begin{array}{l}\text { Immigrants' Language Skills: The Australian } \\
\text { Experience in a Longitudinal Survey }\end{array}$ & 1 & 05/02 \\
\hline 503 & $\begin{array}{l}\text { R. Winter-Ebmer } \\
\text { A. Wirz }\end{array}$ & $\begin{array}{l}\text { Public Funding and Enrolment into Higher } \\
\text { Education in Europe }\end{array}$ & 3 & $05 / 02$ \\
\hline 504 & $\begin{array}{l}\text { L. Cappellari } \\
\text { S. P. Jenkins }\end{array}$ & Modelling Low Income Transitions & 4 & $05 / 02$ \\
\hline 505 & T. K. Bauer & Migration, Sozialstaat und Zuwanderungspolitik & 1 & $05 / 02$ \\
\hline 506 & $\begin{array}{l}\text { P. Díaz-Vázquez } \\
\text { D. Snower }\end{array}$ & Can Insider Power Affect Employment? & 3 & $05 / 02$ \\
\hline 507 & $\begin{array}{l}\text { E. Fehr } \\
\text { A. Falk }\end{array}$ & Psychological Foundations of Incentives & 5 & 05/02 \\
\hline 508 & $\begin{array}{l}\text { C. Belzil } \\
\text { J. Hansen }\end{array}$ & Unobserved Ability and the Return to Schooling & 6 & 05/02 \\
\hline 509 & A. Kunze & $\begin{array}{l}\text { The Timing of Careers and Human Capital } \\
\text { Depreciation }\end{array}$ & 1 & 06/02 \\
\hline 510 & E. S. Prasad & Wage Inequality in the United Kingdom, 1975-99 & 2 & 06/02 \\
\hline
\end{tabular}

